\title{
COMMENTARY
}

\section{POLITICS BY OTHER MEANINGS: \\ A COMMENT ON "RETAKING RATIONALITY TWO YEARS LATER"}

Douglas A. Kysar

TABLE OF CONTENTS

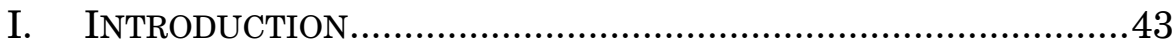

II. NUDGES, FUDGES, AND SHOVES ……………………….......... 48

III. The Social Costs of the Social Cost OF CARBon .............57

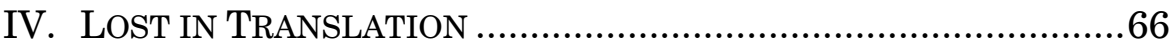

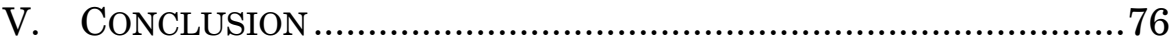

\section{INTRODUCTION}

In an address based on Dean Revesz's 2010 Frankel Lecture, ${ }^{1}$ Michael Livermore and Richard Revesz revisit their important and influential book, Retaking Rationality: How Cost-Benefit Analysis Can Better Protect the Environment and Our Health. ${ }^{2}$ In that book, the authors argue that proponents of environmental, health, and safety regulation have unwisely marginalized themselves by refusing to engage debate over how

\footnotetext{
Joseph M. Field '55 Professor of Law, Yale Law School. I am grateful to Ryan Bubb, Sasha Post, Amy Sinden, Rena Steinzor, and Lindsey Trachtenberg for helpful comments and discussion. This Commentary relies heavily on research and analysis by colleagues at the Center for Progressive Reform. For an overview of the Center's work in this area, go to http://www.progressivereform.org/regPolicy.cfm.

1. Michael A. Livermore \& Richard L. Revesz, Retaking Rationality Two Years Later, 48 Hous. L. REV. 1 (2011).

2. Richard L. Revesz \& Michael A. Livermore, Retaking Rationality: How Cost-Benefit Analysis Can Better Protect the Environment and Our Health (2008).
} 
best to conduct economic cost-benefit analysis of proposed regulations. As a result, the approach to cost-benefit analysis that has tended to dominate within Washington, D.C. reflects a lopsided set of assumptions and arguments, primarily serving the interests of regulated industries. ${ }^{3}$ As Livermore and Revesz note in their address, "[t]his basic political dynamic, which was present at the founding moment of aggressive cost-benefit analysis-based regulatory review, informed the development of cost-benefit analysis in the United States for at least three decades and continues to exert considerable pull today." ${ }^{\prime 4}$ Thus, even as a "bipartisan consensus [has been] crystallizing" in favor of cost-benefit analysis as a useful device for evaluating public policy, the environmental, health, and safety advocacy community remains largely opposed to its use. ${ }^{5}$ Not only has this oppositional stance allowed advocacy groups "to be portrayed as regulatory zealots, seeking ever higher standards no matter the costs," it also has meant that numerous opportunities to improve the practices and principles of cost-benefit analysis have been missed. $^{6} \quad$ Retaking Rationality powerfully outlines those opportunities and encourages the advocacy community to abandon their objections and "get in the game" of using cost-benefit analysis to justify environmental, health, and safety protection."

The two years that followed publication of Retaking Rationality offered ample opportunity to evaluate the book's central message. President Obama campaigned on a platform that included strong environmental messages, including a commitment to engage the climate change problem promptly and aggressively. ${ }^{8}$ In the opening moments of his administration, President Obama also signaled a strong desire to "mend it, not end it" when it comes to cost-benefit analysis, both by nominating Cass Sunstein to head the Office of Information and Regulatory Affairs (OIRA) within the White House Office of Management and Budget (OMB)

3. See id. at 9-11 (admonishing "liberals" for "ceding" the debate on cost-benefit analysis, which ultimately led to the abundance of "antiregulatory biases" found in today's version of cost-benefit analysis).

4. Livermore \& Revesz, supra note 1 , at 6 (footnote omitted).

5. $\quad$ Id. at 7 .

6. Id. at 8 .

7. See REVESZ \& LIVERMORE, supra note 2, at 10-12 (explaining that cost-benefit analysis is inevitable and criticizing environmentalists and other proregulatory interest groups for allowing "the guidelines [to be] created with empty chairs in the room").

8. See Barack Obama and Joe Biden: Promoting a Healthy Environment, BARACKOBAMA.COM, http://www.barackobama.com/pdf/issues/EnvironmentFactSheet.pdf (last visited Mar. 5, 2011) (detailing the Obama campaign's environmental platform).

9. Cf. Livermore \& Revesz, supra note 1, at 2 (suggesting a strategy of "'mending, not ending' cost-benefit analysis" (quoting REVESZ \& LIVERMORE, supra note 2, at 10)). 
and by issuing an announcement that regulatory cost-benefit analysis would be retained in his administration but subjected to a thorough reevaluation to ensure consistency with such progressive goals as transparency in governance, incorporation of distributional and fairness concerns, respect for the interests of future generations, and avoidance of undue delay in rulemaking. ${ }^{10}$ Subsequently, a series of high-profile disasters unfolded that might well have focused public attention on the importance of reforming energy, environmental, and climate change policies, underscoring both the direct and the secondary or ancillary benefits of reducing greenhouse gas emissions and fossil fuel dependency that Livermore and Revesz rightly stress in their work. ${ }^{11}$ These disasters included the release of some 5.4 million cubic yards of potentially toxic coal ash from the Kingston Fossil Plant in Tennessee, ${ }^{12}$ the worst U.S. mine disaster in more than four decades at the Upper Big Branch mine in West Virginia, ${ }^{13}$ and the largest marine oil spill in history following an explosion that killed eleven workers on the Deepwater Horizon Oil rig in the Gulf of Mexico. ${ }^{14}$ In contrast to earlier disasters such as Hurricane Katrina, scientists also began to positively link extreme weather events to climate change, including massive fires and a deadly heat wave in Russia that was several standard deviations outside of normal fluctuations; ${ }^{15}$ flooding in Pakistan that killed more than

10. See Memorandum for the Heads of Executive Departments and Agencies, 3 C.F.R. 343 (2010) [hereinafter Obama Memorandum] (implying continuance of cost-benefit analysis by instructing the Director of the OMB to provide "suggestions on the role of cost-benefit analysis" and suggesting the promulgation of a new executive order).

11. Livermore \& Revesz, supra note 1 , at 8-10. For a more extensive discussion explaining ancillary benefits, see Samuel J. Rascoff \& Richard L. Revesz, The Biases of Risk Tradeoff Analysis: Towards Parity in Environmental and Health-and-Safety Regulation, 69 U. CHI. L. REV. 1763, 1790-1813 (2002).

12. Matthew Pearl, The Aftermath of the December 2008 Incident in East Tennessee Illuminates the Inadequate Regulation of Coal Ash Impoundments, 16 U. BALT. J. ENVTL. L. 195, 195-96 (2009).

13. Ian Urbina, No Survivors Found at Site of W. Va. Mine Disaster, N.Y. Times, Apr. 10, 2010, at A1.

14. Clifford Krauss, Oil Spill's Blow to BP's Image May Eclipse Out-of-Pocket Costs, N.Y. TIMES, Apr. 30, 2010, at B1; Campbell Robertson \& Clifford Krauss, Gulf Spill Is the Largest of Its Kind, Scientists Say, N.Y. TIMES, Aug. 3, 2010, at A14.

15. But see NAT'L OCEANIC \& ATMOSPHERIC ADMIN., U.S. DEP'T OF COMMERCE, THE RUSSIAN HEAT WAVE OF 2010 (2010), available at http://www.esrl.noaa.gov/psd/csi/ moscow2010/ (indicating, in a draft report, that the Russian heat wave was caused by the meteorological phenomenon of "blocking"). This draft report concludes that "greenhouse gas forcing fails to explain the 2010 heat wave over western Russia," primarily because it is not yet understood how "greenhouse gas emissions may affect the frequency or intensity of blocking during summer," which is the direct atmospheric cause of the heat wave. Id. Other atmospheric scientists disagree and believe global warming at least played a role in exacerbating the Russian heat wave. Christine Dell'Amore, Russia Fires, Pakistan Floods Linked?, NAT'L GEOGRAPHIC DAILY NEWS (Aug. 11, 2010), http://news.nationalgeographic.com/ 
1,700 people and destroyed billions of dollars worth of crops and infrastructure, ${ }^{16}$ and-surprisingly-the severe cold and snowstorms that affected the Northeastern and Mid-Atlantic United States during the winter of 2009-2010. ${ }^{17}$ All of these developments coupled with solid Democratic majorities in both houses of Congress during the beginning of Obama's presidency seemed to set the stage for significant progress in the areas of environmental, health, and safety protection, supported by more rigorous and humane cost-benefit analysis of just the sort that Livermore and Revesz advocate in Retaking Rationality.

Unfortunately, a global economic recession also coincided with these developments and worked to destroy all apparent political appetite in the United States for environmental, health, and safety reform, especially in the area of climate change. Undoubtedly, the recession complicates any effort to assess the impact of improvements to cost-benefit analysis that may have been achieved over the past two years: given the enormity of the recession's influence on public attitudes and political momentum, it would be foolish to speculate whether President Obama's

news/2010/08/100812-russian-wildfires-pakistan-floods-global-warming-science-environment/. The developing field of climate attribution science will help refine these conclusions, as this field offers ways of measuring the degree to which the probability of extreme weather events has been increased by anthropogenic warming. See Dáithí A. Stone et al., The Detection and Attribution of Human Influence on Climate, 34 ANN. REv. ENV'T \& RESOURCES 1, 9-12 (2009) (explaining research methods for the study of climate attribution). For instance, a study of the 2003 European heat wave, which resulted in the premature death of at least 35,000 people, concluded that the heat wave was two times more likely to have occurred as a result of the human contribution to global warming. Peter A. Stott, D.A. Stone \& M.R. Allen, Human Contribution to the European Heatwave of 2003, 432 NATURE 610 (2004); see also Janet Larsen, Plan B Updates: Setting the Record Straight: More than 52,000 Europeans Died from Heat in Summer 2003, EARTH POL'Y Inst. (July 28, 2006), http://www.earth-policy.org/index.php?/plan_b_updates/2006/update56 (reporting that early data indicating a death toll from the heat wave of approximately 35,000 underestimated the actual number of heat-related deaths by 17,000).

16. Louise Gray, Pakistan Floods: Climate Change Experts Say Global Warming Could Be the Cause, TELEGRAPH (Aug. 10, 2010, 9:00 PM), http://www.telegraph.co.uk/ news/worldnews/asia/pakistan/7937269/Pakistan-floods-climate-change-experts-say-globalwarming-could-be-the-cause.html; Pakistan Flood Damage Estimated at \$9.7 Billion, CNN WORLD (Oct. 14, 2010), http://articles.cnn.com/2010-10-14/world/ pakistan.flood.cost_1_southern-sindh-province-malaria-cases-world-bank?_s=PM:WORLD.

17. The extreme cold and heavy snowstorm events experienced by the Eastern United States were attributed to a shift in Arctic air circulation patterns following release of greater levels of warmth that had been absorbed during Arctic summers due to declining sea ice. See J. Overland, M. Wang \& J. Walsh, Atmosphere, in ARCTIC REPORT CARD: UPDATE FOR 2010 8, 11, 15 (2010), http://www.arctic.noaa.gov/reportcard/ ArcticReportCard_full_report.pdf. One hopes that this report was read by Senator Inhofe, who built an igloo with his family near the U.S. Capitol following a February 2010 snowstorm and dubbed it "Al Gore's New Home" in an apparent attempt to cast doubt on the reality of climate change. John M. Broder, Climate Fight Is Heating Up in Deep Freeze, N.Y. Times, Feb. 11, 2010, at A1. 
embrace of cost-benefit analysis-as opposed to the more overtly moralized rhetoric favored by the advocacy community-causally contributed to the dearth of policy achievements over the last two years as weighed against promises and expectations formed during the campaign. Rather than attempt such a speculation, this Commentary, instead, will focus analytically on areas of improvement in the practice of cost-benefit analysis that Livermore and Revesz highlight in their address, asking whether they do in fact represent salutary changes from prior practice. The specific areas addressed will be the incorporation of behavioral insights into regulatory design and impact analysis; the development of a uniform social cost of carbon for use in evaluating federal climate change regulations; and the institutional reform of cost-benefit analysis practice to become more transparent and inclusive. It will be argued that many of these areas do indeed reflect valuable changes from prior practice, most notably in the emergence of an attitude of humility and circumspection within the cost-benefit community with respect to estimating the social cost of carbon. Nevertheless, it will also be argued that the environmental, health, and safety advocacy community still faces a strategic dilemma more challenging and poignant than Livermore and Revesz appear to acknowledge.

The developments reviewed in Livermore and Revesz's address and in this Commentary underscore the fact that cost-benefit analysis is less certain and more pliable than ever before. In practice, the "game" of regulatory cost-benefit analysis is just that, a structured exercise in which competing interests pursue policy outcomes not through direct argument and suasion, but through use of alternative assumptions, valuation techniques, discount rates, and other seemingly technical trappings of the cost-benefit methodology. As a result, subjects of ordinary moral and political discourse become debated through a stylized cost-benefit vernacular. This form of "politics by other meanings" has the benefit of tempering debate that might otherwise boil over into moralistic mud-slinging, culture wars, or worse. The "cool" language of costs and benefits just does not seem to engage people's basic beliefs and worldviews in the same way as "hot" languages, such as religion and morality. ${ }^{18}$ But this cooling also

18. Cf. Dan M. Kahan, The Secret Ambition of Deterrence, 113 HARV. L. REV. 413, 476-77 (1999) (noting that the language of deterrence is used in issues like capital punishment, gun control, and hate crimes because "it doesn't speak to the contested expressive values that make these matters so contentious" but rather "cools . . . an engine of debate that is predisposed to run at a white hot temperature"). 
poses considerable costs, as this Commentary will attempt to show. Ultimately, what appears most sensible is that some segments of the environmental, health, and safety advocacy community follow Livermore and Revesz's advice and become adept at playing the cost-benefit game in hopes of upsetting the current dynamic, which heavily favors regulated entities. Other segments, however, should continue to speak different truths to those same powers.

\section{NUDGES, FUDGES, AND SHOVES}

As Livermore and Revesz note, one major development in the cost-benefit arena appears to be the mainstreaming of "behavioral" approaches to policy design, implementation, and evaluation. ${ }^{19}$ Although signaled early through President Obama's announcement regarding the possibility of a new executive order on regulatory impact analysis, ${ }^{20}$ this behavioral turn appeared most strongly in the OMB's annual report to Congress on the costs and benefits of federal regulatory programs ${ }^{21}$ and in a letter from Sunstein to agency heads that stressed the importance of using cognitive psychology, behavioral economics, and other social sciences in the crafting of regulations. ${ }^{22}$ These recommendations appeared to come straight from the pages of Nudge, Sunstein's popular book cowritten with Richard Thaler. Nudge argues that conservatives and liberals should be able to agree on a wide variety of soft regulatory interventions-ones designed to alter the "choice architecture" of individuals in a way that improves well-being without directly forcing behavioral changes. ${ }^{23}$ A favorite example from Nudge involves the use of a painted fly image inside the urinals of men's bathrooms, which

19. See Livermore \& Revesz, supra note 1, at 19-23 (illustrating that the Obama Administration has, through the guidance of Cass Sunstein, integrated behavioral economics into regulatory decisionmaking).

20. Obama Memorandum, supra note 10.

21. Office of Mgmt. \& Budget, Exec. Office of the President, 2009 Report to CONGRESS ON THE BENEFITS AND COSTS OF FEDERAL REgulations AND UnFunded MANDATES ON STATE, LOCAL, AND TRIBAL ENTITIES 35-37 (2009), available at http://www.whitehouse.gov/sites/default/files/omb/assets/legislative_reports/2009_final_ BC_Report_01272010.pdf [hereinafter 2009 OMB REPORT].

22. See Memorandum from Cass R. Sunstein, Adm'r, OIRA, to the Heads of Exec. Dep'ts \& Agencies (June 18, 2010), available at http://www.whitehouse.gov/sites/ default/files/omb/assets/inforeg/disclosure_principles.pdf (discussing strategies for implementing disclosure as a regulatory tool to measure individual and group behavior).

23. See Richard H. Thaler \& CASS R. Sunstein, Nudge: Improving DECisions ABout HeAlth, WEALTH, AND HAPPINESS 13-14, 183-96 (2008) (analyzing how through using subtle "nudges," such as better incentives and better feedback, regulations can work to improve the environment). 
apparently dramatically improves aim and thereby reduces cleaning costs. ${ }^{24} \mathrm{~A}$ weightier example is the use of an "opt-out" as opposed to an "opt-in" default standard for retirement savings programs, which can substantially enhance participation rates. ${ }^{25}$ The idea is that, for a variety of reasons, individuals tend to underestimate their long-term savings needs. Altering the choice architecture in this way helps to overcome those cognitive limitations while still permitting individuals to opt-out if they desire.

These are fine policies as far as they go, but the question remains: How far do they go? In its annual report, OMB wrote that "[b]ehaviorally informed approaches can be applied in many domains, including financial regulation, public health, environmental protection, energy use, motor vehicle safety, and consumer protection." ${ }^{26}$ But the effectiveness and reach of nudges depends very much on context and goal. Take information disclosure rules, for instance. The OMB report suggests that mere disclosure of information on toxic chemical releases by businesses, as required under the federal Toxic Release Inventory program, can have a significant effect on behavior. ${ }^{27}$ No doubt reported releases have gone down, but it is not entirely clear whether these reports reflect actual reductions in releases or strategic reorganizations by regulated entities to avoid triggering whatever reporting threshold has been specified in the disclosure program. An important study by Lori Snyder Bennear of a similar disclosure regime at the state level in Massachusetts suggests the latter, concluding that up to $40 \%$ of an apparent decline in toxic releases in that state may actually represent strategic adjustments to avoid reporting requirements. $^{28}$ How widespread is this problem of circumvention and might behavioral-based regulations be especially vulnerable to it given their softness? It would be nice to know the answer before we give up on old-fashioned regulatory shoves.

\footnotetext{
24. Id. at $3-4$.

25. See id. at 108-09 (comparing participation in retirement enrollment plans-approximately $20 \%$ enrollment rate after three months of retirement plans that were "opt-in" versus an immediate $90 \%$ enrollment rate of plans that were "opt-out").

26. 2009 OMB REPORT, supra note 21, at 37.

27. See id. at 38 (praising the disclosure requirements of the Emergency Planning and Community Right-to-Know Act for their "significant beneficial effects, spurring reductions in toxic releases throughout the United States").

28. Lori S. Bennear, What Do We Really Know? The Effect of Reporting Thresholds on Inferences Using Environmental Right-to-Know Data, 2 REG. \& GOVERNANCE 293, 295, 304 (2008).
} 
Even when a behavioral nudge $i s$ effective, the effect may be slight in comparison to our regulatory needs. For instance, household electricity consumption might indeed go down if we nudge individuals with emoticons on their utility bills that reveal whether they are more or less demanding than their neighbors. ${ }^{29}$ But even the most bullish estimates of greenhouse gas emissions reductions attainable through household efficiency measures merely suggest a slowing of growth in projected energy consumption. $^{30}$ Overhyped scientific flaps notwithstanding, the world's climate change experts agree that if we are to avoid potentially catastrophic and irreversible alteration of our atmosphere, oceans, and other planetary systems, we need to radically alter the way in which we provide energy, transportation, housing, food, and other essentials to humans everywhere on earth. ${ }^{31}$ Behavioral nudges appear to be "weak sauce" in the face of such a mega challenge-a limitation that Sunstein and Thaler do acknowledge in their book, which is why they instead advocate a cap-and-trade system for reducing greenhouse gas emissions. ${ }^{32}$ Still, even a cap-and-trade or other market-based system may fail to deliver the transformation needed most critically because, as discussed below in Part III, they tend to be tied to economic cost-benefit analyses that are "tuned" only to recommend marginal, incremental changes to an otherwise unquestioned status quo.

29. See Ian Ayres, Sophie Raseman \& Alice Shih, Evidence from Two Large Field Experiments that Peer Comparison Feedback Can Reduce Residential Energy Usage 1 (Nat'l Bureau of Econ. Research, Working Paper No. 15386, 2009), available at http://www.nber.org/papers/w15386 (explaining that descriptive and injunctive messages, including emoticons, have lowered energy consumption in at least two separate studies). On the other hand, a study of electricity usage among Californian households by Dora Costa and Matthew Kahn found that conservatives tend to ignore comparative electricity use information or even increase their consumption in response to such information. See Dora L. Costa \& Matthew E. Kahn, Energy Conservation "Nudges" and Environmentalist Ideology: Evidence from a Randomized Residential Electricity Field Experiment 2-4, 15-16 (Nat'l Bureau of Econ. Research, Working Paper No. 15939, 2010), available at http://www.nber.org/papers/w15939.

30. See, e.g., HaNnaH Choi Granade ET AL., MCKinsey \& Co., Unlocking ENERGy EFFICIENCY IN THE U.S. ECONOMY 7, 8 \& exhibit 2 (2009), available at http://www.mckinsey.com/clientservice/electricpowernaturalgas/downloads/us_energy_ efficiency_full_report.pdf (illustrating that increased energy efficiency will only slow the rate of growth); Natural Res. Def. Council, Policy Brief: Boosting EnERgy EfFiciency NATIONwide Through MEASUREMENT AND PERFORMANCE-BASED REWARDS (2009), available at http://www.nrdc.org/globalWarming/cap2.0/files/efficiencyperformance.pdf (examining the effects of programs designed to increase energy efficiency).

31. See, e.g., G8+5 Academies' Joint Statement: Climate Change and the TRANSFORMATION OF ENERGY TECHNOLOGIES FOR A LOW CARBON FUTURE (2009), available at http://www.nationalacademies.org/includes/G8+5energy-climate09.pdf ("Climate change and sustainable energy supply are crucial challenges for the future of humanity.").

32. ThAlER \& SUnStEIN, supra note 23 , at 184-86. 
To date, our most successful environmental, health, and safety regulations have come in the form of shoves, not nudges. And the shoves have not been market-based: the Clean Air Act, which dominates OMB's table of monetized regulatory benefits from federal regulations, ${ }^{33}$ is primarily built on health-based and technology-based standards, not on the kind of nudge-based or market-based regulations that now crowd environmental policy discussions. Even the much vaunted acid rain trading program, which proponents claim has "proven" the effectiveness of cap-and-trade, presents a decidedly unclear lesson when studied carefully. Much of the program's apparent success has come from regulatory and economic developments unrelated to the cap-and-trade feature itself, and the program's future is clouded by a potential problem of overallocated and banked permits-a problem that seems well-nigh universal to cap-and-trade programs. $^{34}$ Because cap-and-trade and other greenhouse gas legislation is all but dead in Congress, the burden has fallen to the Environmental Protection Agency (EPA) to implement greenhouse gas controls through the Clean Air Act. Yet a worry remains that OIRA - which will oversee the EPA's efforts using cost-benefit analysis, notwithstanding the choice of alternative standards in the Clean Air Act itself ${ }^{85}$-aims to set up a presumption in favor of nudge-based regulation, perhaps followed by market-based schemes like cap-and-trade if nudges are shown to be inadequate, and then finally to traditional regulatory techniques if market-based approaches are demonstrated ineffective. Based on our actual history with regulatory design and implementation, however, the presumptions should well work in the opposite direction.

At the risk of sounding like one of the paranoid cost-benefit opponents that Livermore and Revesz seek to calm and encourage, the addition of behavioral economics and related insights to regulatory impact analysis seems to be working in a predictably antiregulatory fashion. Rather than offering a set of complementary policy tools that stand alongside more traditional

33. See 2009 OMB REPORT, supra note 21, at 10-11 tbl.1-2 (the Office of Air's estimated benefits are 82 to 580 million dollars; the next closest regulation has only 16 to 17 million dollars in benefits).

34. See Lesley K. McAllister, The Overallocation Problem in Cap-and-Trade; Moving Toward Stringency, 34 CoLUM. J. ENVTL. L. 395, 412-13 (2009) (noting that "emissions were falling between 1990 and 1995 due to economic factors unrelated to the [Acid Rain Program]" and that the Acid Rain Program was "characterized by early overallocation").

35. Cf. Lisa Heinzerling, Statutory Interpretation in the Era of OIRA, 33 FORDHAM URB. L.J. 1097, 1104-06 (2006) (describing OIRA's stringent review of rules enacted by the EPA under the Clean Water Act). 
regulatory measures, the behavioral turn seems instead to be adding another layer of gamesmanship within which proponents of environmental, health, and safety protection must compete, struggling to overcome a series of ideological presumptions against altering the status quo. Consider the role of behavioral insights in two recent and significant rulemakings. First, the National Highway Traffic Safety Administration (NHTSA) sought to implement a requirement of the 2007 federal energy bill that the agency create a Tire Fuel Efficiency Consumer Information Program, consisting of both a rating system of tire fuel efficiency and a labeling program to convey the information to consumers. ${ }^{36}$ Despite the fact that the agency conducted extensive focus group and survey testing of its proposed labeling program, OIRA rejected it because the agency had not conducted "scientifically valid experiments" that were capable of quantifying "consumers' understandings of the label." Thus chastened, NHTSA only was able to finalize its rules for tire fuel efficiency rating, and the agency continues to work on OIRA's demand for further research with respect to labeling. ${ }^{38}$ When it eventually proposes a new labeling program, NHTSA will be forced to undergo another notice and comment period and OIRA review process. Thus, the incorporation of behavioral insights here seems to have strengthened the burden of proof facing the regulating agency, adding further cost and delay to the rulemaking process.

Next, consider the EPA's experience attempting to regulate coal ash waste, the most hotly contested environmental, health, and safety issue in the Obama Administration to date. ${ }^{39}$ In this long overdue rulemaking, ${ }^{40}$ the EPA proposed to regulate coal ash

36. Letter from Cass R. Sunstein, Adm'r, OIRA, to David Strickland, Adm'r, NHTSA (Mar. 19, 2010), available at http://www.reginfo.gov/public/postreview/ Tire_Fuel_Efficiency_Consumer_Information_Final_Rule.pdf.

37. Id.

38. Tire Fuel Efficiency Consumer Information Program, 75 Fed. Reg. 15,894, 15,900 (Mar. 30, 2010) (to be codified at 49 C.F.R. pt. 575).

39. This proposal has attracted intense scrutiny, with OIRA meeting some forty-two times with interested parties; an amount which, at the time, represented more than half of all OIRA meetings on EPA rules and some 30\% of all OIRA meetings on any Obama Administration rule. James Goodwin, Eye on OIRA: Coal Ash Meetings Up to 42, or More Than Half of All OIRA Meetings on EPA Rules, CPR BLOG (Apr. 5, 2010), http://www.progressivereform.org/CPRBlog.cfm?idBlog=CE877002-A1A5-ADAC-34017 AC4184F218A. "[OIRA's] review of the [EPA's proposed] coal ash rule lasted over six months-well past the 120-day limit that Executive Order 12866 allowe[ed]." Letter from Sidney Shapiro et al., Ctr. for Progressive Reform, to OIRA (June 23, 2010), available at http://www.progressivereform.org/articles/2010_CPR_Comments_OMB_report.pdf [hereinafter Letter to OIRA]

40. The EPA has proposed regulating coal ash as hazardous waste since 1978. Hazardous Waste Guidelines and Regulations, 43 Fed. Reg. 58,946, 59,015 (proposed Dec. 
that is a byproduct of electricity production and that contains a variety of heavy metals, carcinogens, and other materials known to be hazardous to human health. Over 100 million tons of the waste are generated each year and threaten to contaminate groundwater and cause harmful ecological and human health effects, both by leaching from unlined waste impoundments and through catastrophic releases such as the 2008 Kingston incident. ${ }^{41}$ The EPA originally recommended that coal ash be listed as a Subtitle C "hazardous waste" and subjected to the requirements of the Resource Conservation and Recovery Act (RCRA). ${ }^{42}$ Following OIRA review, however, the agency revised the proposal to include both its original plan (albeit with an unprecedented "special waste" designation in place of the familiar "hazardous waste" terminology) and another significantly less stringent alternative that would essentially treat coal ash little different from household waste. ${ }^{43}$ Although OIRA's concerns about the EPA's original proposal were many, one prominent argument raised in support of watering down the proposal was a speculative concern by industry that classification of coal ash as a hazardous waste might give rise to a "stigma effect" whereby the beneficial reuse of coal ash would no longer be economically viable. ${ }^{44}$ At present, some coal ash is recycled and used in road paving material, construction concrete, and other safe and beneficial applications. ${ }^{45}$ Even though the EPA was careful to note in the proposal that it was not altering an earlier determination that such beneficially reused coal ash is exempt from RCRA's hazardous waste regulations, ${ }^{46}$ industry

18, 1978) (codified at 40 C.F.R. pt. 250); see also Final Regulatory Determination on Four Large-Volume Wastes from the Combustion of Coal by Electric Utility Power Plants, 58 Fed. Reg. 42,466, 42,466 (Aug. 9, 1993) (codified at 40 C.F.R. pt. 261) (memorializing the initial EPA proposal to regulate coal ash in December 1978).

41. Hazardous and Solid Waste Management System; Identification and Listing of Special Wastes; Disposal of Coal Combustion Residuals from Electric Utilities, 75 Fed. Reg. 35,128, 35,132, 35,143 (proposed June 21, 2010) (to be codified at 40 C.F.R. pts. 257, $261,264,265,268,271,302$ ).

42. Hazardous Waste Guidelines and Regulations, 43 Fed. Reg. at 58,891; Letter to OIRA, supra note 39 , at 5-6.

43. Letter to OIRA, supra note 39 , at 5-7.

44. Hazardous and Solid Waste Management System; Identification and Listing of Special Wastes; Disposal of Coal Combustion Residuals from Electric Utilities, 75 Fed. Reg. at $35,156,35,159$.

45. See Citizens for Recycling First, Proposed EPA Disposal Regulations Threaten Coal Ash Recycling, http://www.recyclingfirst.org/pdfs/53.pdf (last visited Mar. 5, 2011) (commending coal ash's ability to strengthen concrete, reduce the use of cement, and "conserve[ ] natural resources and save[ ] energy").

46. See Hazardous and Solid Waste Management System; Identification and Listing of Special Wastes; Disposal of Coal Combustion Residuals from Electric Utilities, 75 Fed. Reg. at 35,129 ("EPA is not proposing to affect the current status of coal combustion 
representatives argued that stringent regulation of remaining coal ash would unduly "taint" beneficially reused waste material. ${ }^{47}$ The price tag for this unintended behavioral consequence of regulation- $\$ 233.5$ billion in lost benefits-was an amount that dramatically tilted the cost-benefit calculus against regulation. ${ }^{48}$ For its part, OIRA seems to have been so taken with industry's argument that it admonished the EPA not to even identify the Subtitle C option as "preferred" among the new alternatives because that designation "alone may have unintended consequences on beneficial reuse, even if an alternative option is selected for final [adoption]."49

Empirical support for the coal ash "stigma effect" is surprisingly thin, despite the significance afforded it during the regulatory review process. The argument seems to be that "[e]nd users of products containing coal ash are highly susceptible to messages that create fear and doubt. (Do you want hazardous waste in your home and your child's school?)" ${ }^{, 50}$ As Rena Steinzor has argued, actual academic research on stigma effects appears both difficult to interpret and far afield from the specific context of coal ash reuse. ${ }^{51}$ One study cited by Sunstein, for instance,

residuals [or coal ash] that are beneficially used."); $i d$. at 35,128 ("EPA is not proposing to change the May 2000 Regulatory Determination for beneficially used CCRs, which are currently exempt from the hazardous waste regulations ...."); id. at 35,162 ("EPA does not wish to inhibit or eliminate the significant and measurable environmental and economic benefits derived from the use of this valuable material without a demonstration of an environmental or health threat.").

47. An industry front group known as Citizens for Recycling First has been a leading purveyor of this stigma theory. See Citizens for Recycling First, supra note 45 ("The 'Subtitle C hazardous' approach would seriously damage recycling by creating an unnecessary hazardous waste stigma on coal ash."). The stigma claim also has been repeatedly urged by industry representatives in various hearings. For an example of one of these hearings, see Coal Combustion Byproducts: Potential Impact of a Hazardous Waste Designation on Small Businesses in the Recycling Industry: Hearing Before the H. Comm. on Small Bus., 111th Cong. 19-20, 45-49 (2010) (statement of Thomas H. Adams, Executive Director, American Coal Ash Association) ("We believe this 'hazardous' designation would create a stigma resulting in rejection by the market place ....").

48. See Rena Steinzor, OIRA's Fuzzy Math on Coal Ash: A Billion Here, a Billion There, CPR BLOG (July 13, 2010), http://www.progressivereform.org/ CPRBlog.cfm?idBlog=CD428D4F-DCDE-9091-533F4195CE25C5E4 (characterizing the high cost of the "stigma effect" as "dwarf[ing] any expected benefits of regulation by several orders of magnitude").

49. Interagency Working Comments on Draft Rule Under EO 12866 (Document ID: EPA-HQ-RCRA-2009-0640-0350)， REGULATIONS.GOV (May 20, 2010, 12:00 AM), http://www.regulations.gov/\#!documentDetail;D=EPA-HQ-RCRA-2009-0640-0350 [hereinafter Interagency Working Comments] (open document by clicking on the PDF icon).

50. Citizens for Recycling First, supra note 45.

51. See Office of Res. Conservation \& Recovery, EPA, Public Hearing on EPA's Proposed Rule on Hazardous and Solid Waste Management System; Identification and Listing of Special Wastes; Disposal of Coal Combustion Residuals from Electric Utilities (Aug. 30, 2010), http://www.epa.gov/osw/nonhaz/industrial/special/fossil/ccr-rule/transcripts/ 
found that subjects were unwilling to drink juice from a glass that had recently contained a cockroach, even though the subjects were assured that the cockroach had been "completely sterilized." ${ }^{52}$ That same study was relied upon by economists in a study for the EPA of Superfund site designation to construct a model of human behavior in which "people replace calculations of risk versus benefit with a simple heuristic of shunning, the avoidance of the stigmatized object." ${ }^{53}$ Just as the heuristics and biases literature more generally has been interpreted to suggest that individuals often misconstrue and mispursue their best interests, ${ }^{54}$ the EPA economists concluded that "while shunning may have evolved from an adaptive response to avoid contaminated food, it can be triggered in inappropriate circumstances." ${ }^{55}$ Thus, because subjects were unwilling to drink juice from a glass that had contained a "sterilized" cockroach-and indeed because "[s]ubjects refused to drink the juice even if it had been in the freezer for one year" ${ }^{256}$-individuals more generally are assumed to be prone to hysterical overreaction to risk. Consistent with this assumption, the EPA economists found that Superfund cleanup delays of ten to twenty years increase the chance of stigmatization for properties surrounding designated sites, such that the benefits of an eventual cleanup may never be reflected in restored property values. $^{57}$

One might be forgiven for wondering what these studies have to do with coal ash. Even the Superfund study sheds little light, as the event triggering taint in that context was a designation of hazardous status by the EPA and a subsequent

transcript-arlington-va.pdf (statement of Rena Steinzor, President, Ctr. for Progressive Reform) (discussing the negative effects of ORIA's cost-benefit analysis).

52. See Christine Jolls \& Cass R. Sunstein, The Law of Implicit Bias, 94 CALIF. L. REv. 969, 974-75 (2006) (citing Paul Rozin, Technological Stigma: Some Perspectives from the Study of Contagion, in RISK, MEDIA, AND STIGMA 31, 32 (James Flynn et al. eds., 2001)).

53. See William Schulze et al., Stigma: The Psychology and Economics of SUPERFUND 23-24 (2004), available at http://yosemite.epa.gov/ee/epa/eerm.nsf/vwAN/ EE-0486-01.pdf/\$file/EE-0486-01.pdf ("Superfund sites might be stigmatized . . . like the 'cockroached' juice.").

54. See Douglas A. Kysar, The Expectations of Consumers, 103 ColUM. L. REV. $1700,1751-56$ (2003) (reviewing and critiquing this literature and discussing the competing theories about the effect of marketing on consumers).

55. See SCHULZE ET AL., supra note 53, at 24.

56. Id. at 23-24. Also of apparent surprise was the fact that "stigma appeared to be insensitive to dose." Id. That is, "[a]ny contact was sufficient for subjects to shun the juice" and "[r]eductions in the duration of contact between juice and cockroach had little effect." Id.

57. Id. at $40,41 \&$ tbl.1.5. 
failure to clean the site up for one or more decades. ${ }^{58}$ In the coal ash context, on the other hand, the EPA has specifically exempted beneficially reused materials from hazardous designation. ${ }^{59}$ Why then was industry allowed to extrapolate from a study on cockroach juice to a multibillion dollar claim about coal ash reuse, while the NHTSA was forced to conduct "scientifically valid experiments" capable of quantifying precise consumer reactions to the precise labeling matter at issue? In these two rulemakings at least, the addition of behavioral sciences seems only to have given industry more weaponry with which to delay regulations and fudge calculation of their impacts. One can only suspect that industry's coal ash argument received prominent attention because OIRA and the White House also opposed the EPA's proposal on other grounds. ${ }^{60}$ Especially unsettling is the fact that researchers at the Institute for Policy Integrity - who have been hard at work putting the messages of Retaking Rationality into practice-conducted a careful, evenhanded cost-benefit analysis of a stringent approach to coal ash regulation and found anticipated net benefits of billions of dollars, even before considering a panoply of nonquantified benefits that also would have followed from stringent regulation. ${ }^{61}$ Yet the Institute for Policy Integrity report appeared little able to influence the coal ash regulatory battle, despite one of the most seemingly friendly political contexts proponents of environmental, health, and safety protection have faced or will face in years.

58. See id. at 8, 36-37 (discussing the effects of stigmatization on property values at Superfund sites where cleanups took longer than expected).

59. Hazardous and Solid Waste Management System; Identification and Listing of Special Wastes; Disposal of Coal Combustion Residuals from Electric Utilities, 75 Fed. Reg. 35,128, 35,128 (proposed June 21, 2010) (to be codified at 40 C.F.R. pts. 257, 261, $264,265,268,271,302)$.

60. An aside: One of the earliest and most influential psychological studies on stigma and taboo was Jonathan Haidt's exploration of the psychology of moral reasoning. Jonathan Haidt, The Emotional Dog and Its Rational Tail: A Social Intuitionist Approach to Moral Judgment, 108 PSYCHOL. REV. 814 (2001). Through a series of vignettes that sought to trigger a taboo response in subjects when instrumental considerations justifying the taboo were absent-such as a hypothetical in which adult siblings decide to engage in sexual relations using two forms of birth control and with no apparent adverse emotional effects-Haidt sought to demonstrate that individuals often experience an intuitive moral judgment first and only then proceed to offer rational accounts of their judgments. $I d$. at 814,817 . In the context of cost-benefit analysis, a similar form of post-hoc reasoning often seems to appear: a political goal is established first and then regulatory impact analyses-including new ones rooted in behavioral science-are constructed to justify the previously established goal.

61. See J. Scott Holladay, Inst. for Policy Integrity, No More Excuses: The ECONOMIC CASE FOR COAL ASH REGULATION 2, 24 (2009), available at http://www.iowadnr.gov/ epc/09jun/nomoreexcuses.pdf. 


\section{THE SOCIAL COSTS OF THE SOCIAL COST OF CARBON}

The most important methodological development for regulatory cost-benefit analysis over the last two years was the creation of a uniform federal measure of the social cost of carbon. An interagency task force was created to conduct this exercise and-although the identity of its members was never revealed, its meeting times and locations disclosed, or its draft report opened to public comment- the task force did solicit some public input to inform its deliberations. The resulting report is notable primarily for its circumspection: throughout the document, the task force acknowledges serious limitations and shortcomings in the cost-benefit methodology as applied to the climate change problem. ${ }^{62}$ Some of these moments of candor and humility even broach fundamental ethical subjects-such as the appropriate treatment of future generations via the discount rate-that cost-benefit proponents have tended to elide in past discussions. ${ }^{63}$ For these reasons and others, the task force should be applauded. Nevertheless, after contemplating the various limitations and shortcomings acknowledged by the task force, it is hard not to be left wondering why a social cost of carbon estimate is useful at all. The more natural conclusion seems to be, as even ardent supporters of cost-benefit analysis have recently acknowledged, ${ }^{64}$ that the social cost of carbon is simply the wrong tool for the climate change job. Indeed, it is a tool that contains-buried deep within its assumptions-deceptively narrow and limited answers to the most fundamental policy questions raised by climate change.

To understand this problem, imagine the pursuit of social-welfare maximization as a quest to crest a mountain. As anyone who has ever climbed an actual mountain knows, the surest route to the top is not the path that follows an incremental

62. For one example of the task force acknowledging this limitation, see

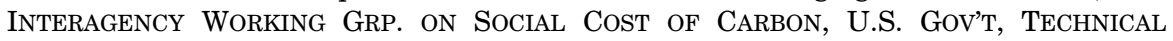
SuPPort DOCUMENT: SOCIAL COST OF CARBON FOR REgulatory IMPACT ANALYsis 4 (2010), available at http://www.epa.gov/otaq/climate/regulations/scc-tsd.pdf [hereinafter TASK FORCE REPORT], wherein the task force states: "In this context, statements recognizing the limitations of the analysis and calling for further research take on exceptional significance. The interagency group offers the new [social cost of carbon] values with all due humility about the uncertainties embedded in them and with a sincere promise to continue to work to improve them."

63. Id. at $17-19$.

64. See Jonathan S. Masur \& Eric A. Posner, Climate Regulation and the Limits of Cost-Benefit Analysis 32-34 (Univ. of Chi. Law Sch., John M. Olin Law \& Economics Working Paper No. 525, 2d series, 2010), available at http://papers.ssrn.com/sol3/ papers.cfm?abstract_id=1662147 (noting the many shortcomings of using the social cost of carbon in a cost-benefit analysis). 
gain in elevation at every step. Nevertheless, constant, steady ascension is a workable heuristic, and it is precisely this heuristic that is offered by cost-benefit analysis: by evaluating proposed changes to the status quo in terms of incremental welfare consequences, cost-benefit analysis promises to determine whether any given policy change will lead us marginally higher up the mountain of social welfare. The fundamental problem in the climate change context is that cost-benefit analysis cannot tell us whether we are on the right mountain. While scrambling meticulously over the details of any cost-benefit exercise, it is easy to lose sight of the fact that at base of the exercise lies a set of fundamental assumptions about resource rights, income distribution, population size, intergenerational equity, international obligation, the state of technology and the likelihood of clean energy innovation, the trajectory of the economy, and so on. Alter these assumptions and one stands on a different mountain, where cost-benefit analysis once again can offer advice on whether a proposed incremental step will lead us up or down. In the climate change context, the near universal view of natural scientists is that we are currently on the wrong mountain. ${ }^{65}$ Indeed, because of tipping points in both ecological and socioeconomic systems, we are heading up a mountain with a cliff at its peak. Thus, we are well-advised at present to take policy steps that may appear inefficient when measured by marginalist cost-benefit analysis that is fixed to the assumptions of the status quo. In other words, we may have to climb down for a while before we can again start ascending a different peak. The ultimate result will be a mountain with a better and more enduring view, but the path of transition will not be a smooth, continuous, and incremental one, as marginalist cost-benefit analysis presumes.

The task force report does stress at the outset this fundamental distinction between choosing and climbing a mountain, or to put the point more technically, between general and partial equilibrium; dynamic and static efficiency; and comprehensive and marginal analysis. ${ }^{66}$ Nevertheless, the authors state in the report that their marginal social cost of carbon estimate will be useful because " $[\mathrm{m}]$ ost federal regulatory actions can be expected to have [only] marginal impacts on global

65. See supra note 31 and accompanying text (explaining that climate change experts argue that basic assumptions about the methods used to provide essentials, such as housing and food, must be altered before any true progress may be made in halting climate change).

66. TASK FORCE REPORT, supra note 62, at 2-4. 
emissions. ${ }^{67}$ The danger here is that the authors' assertion will become self-fulfilling: whether the Clean Air Act offers marginal or inframarginal possibilities for altering greenhouse gas emissions trajectories depends very much on whether the EPA decides to implement the statute with the vigorous health-based and technology-forcing teeth it was originally designed to have. For instance, when viewed individually, energy investment decisions, such as whether to license new coal-fired power plants, may appear to represent only marginal alterations to our status quo trajectory of emissions growth, especially in light of the ever-shrinking share of global emissions that the United States represents as a whole. ${ }^{68}$ But when one considers the durability of such investments-which often exceed even their lengthy planned capital cycles due to the benefit of regulatory grandfathering $^{69}$ - combined with the fact that they occur within a national policy space in which dozens of such individual decisions are constantly being made, then the EPA's implementation of the Clean Air Act may well be seen to raise an infra-marginal decision about the future trajectory of the nation's energy infrastructure. Such an implementation would represent precisely the kind of transformative, general equilibrium-shifting action that the task force authors rightly note may be inappropriate for ordinary cost-benefit analysis. ${ }^{70}$ However, if the EPA's ambitious implementation must be submitted to marginalist cost-benefit review by OIRA, then the significance

67. Id. at 2. This is why it is not entirely a good thing that "market failures remain a central element of regulatory impact analysis," despite the Obama Administration's withdrawal of a formal requirement that specific market failures be identified in connection with rulemaking proposals. Livermore \& Revesz, supra note 1, at 15. Unless the market failure concept is expanded to include an unsustainable general equilibrium as a condition justifying regulatory action, the concept will fail to acknowledge the necessity of market interventions precisely when they are needed most. This is why it is also not obvious that we should seek "much needed consistency across agencies" through use of a uniform social cost of carbon measure. Livermore \& Revesz, supra note 1 , at 25 . Different agencies implementing different statutes will implicate different time horizons and different degrees of potential intervention into the status quo trajectory of greenhouse gas emissions. These different contexts may well require social cost of carbon measures that are tailored specifically to the analytical task at hand.

68. T.A. Boden, G. Marland \& R.J. Andres, Carbon Dioxide Info Analysis Ctr., U.S. Dep't of Energy, United States of America Fossil-Fuel $\mathrm{CO}_{2}$ Emissions: Trends (2010), http://cdiac.esd.ornl.gov/trends/emis/tre_usa.html.

69. See Jonathan Remy Nash \& Richard L. Revesz, Grandfathering and Environmental Regulation: The Law and Economics of New Source Review, 101 Nw. U. L. REV. 1677, 1717-18 (2007) (noting that power plants grandfathered in under the Clean Air Act have been operating far beyond expected retirement dates).

70. See TASK FORCE REPORT, supra note 62, at 2 ("For policies that have a large (nonmarginal) impact on global cumulative emissions, there is a separate question of whether the [social cost of carbon] is an appropriate tool for calculating the benefits of reduced emissions ....”). 
and aim of the regulations will not be understood and will be misleadingly condemned as "inefficient."

The integrated assessment models relied on by the task force all are built on assumptions about matters that are central to the climate change problem but that are not allowed to surface for direct inspection. That is, the cost and benefit outputs of the models depend critically on assumptions about such matters as whether and how quickly economies will decarbonize through technology innovation, what level of adaptive capacity communities will have to lessen the impacts of climate change, what population policies the United States and other nations will pursue, and so on. ${ }^{71}$ These matters are treated as fixed inputs into the models rather than as themselves subjects of policy choice. As a result, regulations altering the trajectory of these matters will be assessed using the social cost of carbon, but the apparent "costs" and "benefits" of such regulations will be misleadingly calculated. For instance, none of the models allow for the possibility that major shifts in U.S. policy will cause other nations to follow suit, such that the business-as-usual emissions trajectory will be lowered by an amount far greater than reflected by the direct reduction of the U.S. policy change. Accordingly, the apparent benefits of U.S. climate policy proposals will be systematically understated by the models if indeed it is true-as countless knowledgeable observers suggest ${ }^{72}$ - that U.S. recalcitrance has become the major stumbling block to international progress.

Consider some further telling examples drawn from the three integrated assessment models used by the task force. ${ }^{73}$ Each of the three models has been criticized in academic literature for making selective and optimistic assumptions about

71. See id. at 4-9, 15 (describing various models relied on by the task force and discussing the underlying assumptions of each model).

72. See, e.g., Rachel Brewster, Stepping Stone or Stumbling Block: Incrementalism and National Climate Change Legislation, 28 YALE L. \& POL'Y REV. 245 (2010) (maintaining that the U.S. policy favoring incremental domestic legislation may impede efforts to develop a comprehensive international approach to combat climate change).

73. Far from "an exhaustive literature review, drawing on the work of the most preeminent scholars in the area," Livermore \& Revesz, supra note 1, at 24, the task force report actually reflects a highly selective sampling of the relevant modeling work. FRANK ACKERMAN \& ElizABETH A. STANTON, THe SOCIAL COST OF CARBON 1, 7 (2010), available at http://sei-us.org/Publications_PDF/SEI-E3-SocialCostCarbon-10.pdf. Indeed, the EPA's "Climate Economic Modeling" webpage does not even list the FUND, PAGE, and DICE models relied upon by the task force but does list several other more complex and updated models not used by the task force. See EPA, Climate Economic Modeling, http://www.epa.gov/climatechange/economics/modeling.html (last updated Sept. 10, 2009) (listing economic model types typically relied upon by the EPA). 
the damages to be expected from a warming world. ${ }^{74}$ The PAGE2002 model, for instance, makes heroic assumptions about the ability of both developed and developing nations to adapt to climate change without cost, ${ }^{75}$ while Richard Tol's FUND model takes such a rosy view of climate change impacts that increased air conditioning costs represent the majority of anticipated damages. ${ }^{76}$ Indeed, the FUND model is built on such optimistic assumptions that it calculates net gains from climate change up to a $3^{\circ} \mathrm{C}$ temperature increase, ${ }^{77}$ even though the active discussion in the natural sciences community is whether even a $2^{\circ} \mathrm{C}$ increase can be sustained without passing a threshold beyond which humanity would suffer fundamental and irreparable harm to life-supporting systems. ${ }^{78}$ The third model-William Nordhaus's long-influential DICE model—does attempt to incorporate catastrophic damages of this sort, but it does so through an outdated and subjective survey that predicts only a $4 \%$ probability of a catastrophe (defined narrowly) at $2.5^{\circ} \mathrm{C}$ warming. ${ }^{79}$ The result is that temperature can increase to

74. See, e.g., ACKERMAN \& STANTON, supra note 73, at 1.

75. See TASK FORCE REPORT, supra note 62, at 7 (assuming that developed countries could adapt to climate change and eliminate up to $90 \%$ of all economic impact and developing countries could eliminate up to $50 \%$ of economic impact).

76. See id. at 8 n.4.

77. See id. at 9 n.5 ("[T] he damages from FUND may cross from negative to positive at less than or greater than $3^{\circ} \mathrm{C}$."). Likewise, the FUND model also finds a substantial reduction in mortality during the early stages of global warming. See id. at 7-8 (describing the FUND model as including "separately calibrated damage functions" for such sectors as sea level rise and human health); Richard S.J. Tol, Estimates of the Damage Costs of Climate Change, 21 ENVTL. \& RESOURCE ECON. 47, 59, 61-62 (2002) (illustrating the "estimated change in mortality" due to a slight rise of global mean temperatures).

78. See James Hansen et al., Target Atmospheric $\mathrm{CO}_{2}$ : Where Should Humanity Aim?, 2 Open ATMOSPHeRIC SCI. J. 217, 225 (2008), http://www.bentham.org/open/ toascj/articles/V002/217TOASCJ.pdf (citing several organizations that have determined as little as a $2^{\circ} \mathrm{C}$ increase could be dangerous). Indeed, at a $5 \%$ discount rate, the FUND model produces a negative total social cost of carbon, given that losses in the far future are unable to overcome the supposed net benefits from warming in the near term. ACKERMAN \& STANTON, supra note 73, at 14-15.

79. TASK FORCE REPORT, supra note 62, at 32. Compare the more recent expert elicitation procedure of Kriegler et al., which found dramatically higher subjective likelihoods for several catastrophic tipping point scenarios over a 50-300 year time horizon and associated with various warming ranges from $0.5-1.5^{\circ} \mathrm{C}$ up to $3-5^{\circ} \mathrm{C}$. Elmar Kriegler et al., Imprecise Probability Assessment of Tipping Points in the Climate System, 106 PROC. NAT'L. ACAD. SCI. 5041, 5044-45 (2009). An important methodological difference between the two surveys is that Kriegler's respondents consisted only of physical scientists asked to estimate the likelihood of specific natural occurrences, while Nordhaus surveyed physical and social scientists and asked them to estimate the likelihood of a catastrophe defined narrowly as a percentage loss of global GDP. Compare id. at 5041, with William D. Nordhaus, Expert Opinion on Climatic Change, 82 AM. SCIENTIST 45, 46-47 (1994). 
unfathomable levels within the DICE model without fundamentally affecting world economic output. Indeed, only one half of global GDP would be lost in the DICE model at a temperature increase of $19^{\circ} \mathrm{C} .^{80}$ Consider this outcome in light of recent calculations of a climate change "adaptability limit" due to the human body's inability to avoid hyperthermia above a certain temperature: "We conclude that a global-mean warming of roughly $7^{\circ} \mathrm{C}$ would create small zones where metabolic heat dissipation would for the first time become impossible, calling into question their suitability for human habitation. A warming of $11-12^{\circ} \mathrm{C}$ would expand these zones to encompass most of today's human population." $" 1$

How can it be that one half of global GDP would continue to be generated and enjoyed at a temperature level several degrees Celsius above this adaptability limit? Quite simply because harm of that sort is an inframarginal event not contemplated by the model's damage function. Rather than positing some degree of fundamental dependence between socioeconomic and natural systems, integrated assessment models typically assume that the economy will continue to function more or less as is, even as damages from climate change grow ever larger. In the extreme, this means that global GDP can continue to pour forth within the models even after all presently inhabited land on earth has been rendered unsuitable for human existence. The possibility of such extreme climate change scenarios suggests that cost-benefit optimizing may simply be the wrong framework for analyzing climate change policy. Rather than optimal consumption smoothing over time, policymakers instead should consider climate change from an insurance perspective, asking how much of present consumption is worth investing in the avoidance of truly intolerable outcomes. ${ }^{82}$ After all, as Frank Ackerman and Elizabeth Stanton note, a typical American family home is only expected to burn down once every 250 years, yet no one foregoes homeowners insurance on the theory that their mean lifetime experience will be fire-free. ${ }^{83}$ Nor do they ask whether insurance is worthwhile to purchase based on

80. See Frank Ackerman, Elizabeth A. Stanton \& Ramón Bueno, Fat Tails, Exponents, Extreme Uncertainty: Simulating Catastrophe in DICE, 69 ECOLOGICAL ECON. 1657, 1660 (2010).

81. Steven C. Sherwood \& Matthew Huber, An Adaptability Limit to Climate Change Due to Heat Stress, 107 Proc. NAT'L. ACAD. SCI. 9552, 9554 (2010).

82. See Martin L. Weitzman, Why the Far-Distant Future Should Be Discounted at Its Lowest Possible Rate, 36 J. EnvTL. ECON. \& MGMT. 201, 202 (1998) ("[W]e must now make investment decisions having consequences that will occur in th[e] hazy future.").

83. ACKERMAN \& STANTON, supra note 73, at 13. 
its costs and benefits adjusted by some decontextualized risk aversion premium. Instead, they ask whether the specific event in question-destruction of their home-is something they can abide. ${ }^{84}$ Policymakers similarly should be asking whether the catastrophic outcomes associated with business-as-usual emissions trajectories represent something that humanity can abide: Does the present generation want to countenance disaster among its legacy of achievements? Because catastrophic climate change scenarios are essentially uninsurable events, this mode of thinking leads to a goal of prevention along lines the scientific community has been urging all along: rather than a system in which all resources are optimally deployed to their highest value use, we should instead seek a system that displays characteristics like precaution, diversification, resilience, redundancy, and innovative capacity-characteristics that may appear to represent an "inefficient" use of resources from a narrow economic viewpoint but that may be essential nonetheless. ${ }^{85}$

Matters worsen when one considers the fundamental model parameter of climate sensitivity, which is a measure of the average global temperature increase associated with a doubling of pre-Industrial atmospheric greenhouse gas concentrations. In this respect, the task force followed prevailing practices by using a climate sensitivity range that does not include long-term feedback effects from temperature increase, such as those that would be associated with loss of continental ice sheets, methane release from oceans and permafrost, Amazonian dieback, and so on. These estimates tend to hover between 1.5 and $4.5^{\circ} \mathrm{C}$, although the range of uncertainty has actually increased as science has progressed-an important and underappreciated

84. See id. (comparing the notion that the cost of prevention will "pale[] in comparison" to "irreversibly destabilizing the earth's climate" with the risk of losing one's house versus the cost of insurance).

85. Even with respect to more mundane consequences of climate change, the three models relied upon by the task force are frustratingly incomplete and selective. For instance, none considers co-benefits of greenhouse gas mitigation, which Livermore and Revesz rightly cite as the most weighty and policy-relevant example of such ancillary benefits of regulation. Livermore \& Revesz, supra note 1, at 9-10. Consequences that are included often seem rather arbitrary. At least in one iteration of the DICE model, anticipated benefits from expanded outdoor recreational opportunities in a warmer world tended to swamp increased mortality and morbidity. See Robert P. Murphy, Rolling the DICE: William Nordhaus's Dubious Case for a Carbon Tax, 14 INDEP. REV. 197, 204-06 \& tbl.1 (2009). For further discussion of this point, see Douglas A. KYSAR, REgulating From Nowhere 110 (2010). The current iteration still seems to include an assumption that most individuals would be willing to pay substantial amounts simply for the benefit of living in a warmer climate. ACKERMAN AND STANTON, supra note 73, at 10-11. 
dynamic in its own right. $^{86}$ A study by Mark Pagani and colleagues attempts to improve climate sensitivity estimates by looking at ice records over extremely long time periods to establish an estimate of climate sensitivity that includes major earth-systems in equilibrium, including long-term feedbacks. ${ }^{87}$ About 5 million years ago, carbon dioxide was as high as or only slightly higher than 2009 values, and the Earth reached temperatures $4^{\circ} \mathrm{C}$ warmer than now, with sea levels tens of meters higher than at present. ${ }^{88}$ Pagani and his colleagues conclude that the climate is much more sensitive than commonly assumed. Indeed, if the researchers' climate sensitivity estimate were applied to our contemporary situation, then even if we stopped emitting today we might still get $2^{\circ} \mathrm{C}$ of warming over time, and if we continue to a doubling of preIndustrial concentrations we could be looking at over $10^{\circ} \mathrm{C}$ of increase, rather than the much more modest amount assumed by the task force. ${ }^{89}$ Recall that $11-12^{\circ} \mathrm{C}$ poses a likely adaptability limit beyond which all currently inhabited land on earth may no longer support human existence. ${ }^{90}$

Of course, paleontology work of the sort conducted by Pagani and his colleagues looks at time horizons that span much longer than might be considered relevant from a policy perspective. ${ }^{91}$ Within cost-benefit analysis, the controversial but prevalent practice of discounting ensures that policy impacts of any size in the far-distant future tend to have little, if any, quantitative significance in determining cost-benefit outcomes. The task force authors again should be applauded for forthrightly and unblinkingly acknowledging that the practice of discounting raises fundamental ethical questions regarding the care and consideration present generations owe to future generations. ${ }^{92}$

86. Mark Pagani et al., High Earth-System Climate Sensitivity Determined From Pliocene Carbon Dioxide Concentrations, 3 NATURE GEOSCIENCE 27, 27 (2010), available at http://www.nature.com/ngeo/journal/v3/n1/pdf/ngeo724.pdf.

87. Id.

88. Id. at 27, 29; Kenneth G. Miller, Sea Level Change, Last 250 Million Years, in ENCYClOPEDIA OF PALEOCLIMATOLOGY AND ANCIENT ENVIRONMENTS 879, 885 fig.57 (Vivien Gornitz ed., 2009).

89. Pagani et al., supra note 86 , at $27,29$.

90. Sherwood \& Huber, supra note 81 , at 9554.

91. See, e.g., Timothy M. Lenton et al., Tipping Elements in the Earth's Climate System, 105 PROC. NAT'L. ACAD. SCI. 1786, 1787, 1791 (2008) (placing limits on "the political time horizon ... based on the human life span and our (limited) ability to consider the world we are leaving for our grandchildren").

92. See TASK FORCE REPORT, supra note 62, at 17 ("The choice of a discount rate, especially over long periods of time, raises highly contested and exceedingly difficult questions of science, economics, philosophy, and law."). 
Nevertheless, the authors did ultimately conclude that discounting, more or less as usual, should be applied in calculating the social cost of carbon, and they did so apparently for no reason other than "consistency with the standard contemporary theoretical foundations of benefit-cost analysis." The particulars of the discounting debate have been reviewed at length elsewhere and will not be recounted here. ${ }^{94}$ For present purposes, it is enough to note that in the climate change context, whether and how to discount exerts such enormous influence on policy recommendations that one wonders whether Livermore and Revesz are correct that proponents of environmental policies are best advised to play within the confines of cost-benefit analysis, rather than try to engage societal discussion regarding the underlying issues of generational responsibility that even economists now acknowledge cannot be resolved by cost-benefit analysis. Discounting is a crude and misleading way to incorporate matters of intergenerational ethics and distributive equity into the welfare-maximization exercise. If OIRA and the agencies insist that climate change policies must be evaluated using discounting, then cost-benefit analysis should be undertaken with the aid of shadow markets, in which natural resources and other environmental goods are first endowed to future generations through sustainability constraints or other

93. Id. at 19 (explaining why a descriptive approach to selecting the discount rate was chosen over a prescriptive approach).

94. See, e.g., Douglas A. Kysar, Discounting ... on Stilts, 74 U. CHI. L. REV 119, 120,138 (2007) (recognizing that "discounting is most controversial when applied to human lives" and also "problematic when applied to ordinary resources"). Dean Revesz has been a leading participant in these discussions. See, e.g., Richard L. Revesz, Environmental Regulation, Cost-Benefit Analysis, and the Discounting of Human Lives, 99 CoLUM. L. REV. 941, 998 (1999) (dismissing "possible justifications for discounting for time preference at a positive rate" as not "compelling"). For his latest contribution, see Richard L. Revesz \& Matthew R. Shahabian, Climate Change and Future Generations (Pub. Law \& Legal Theory Research Paper Series, Working Paper No. 10-59, 2010), available at http://ssrn.com/abstract=1666423, which discusses the flaws in current approaches to discounting benefits that accrue to future generations. It is worthwhile to note here that the task force did not consider evidence of declining discount rates through which individuals express increasing regard for future generations over time, a social science finding that Cass Sunstein has called so important that an agency that does not consider it "should be legally vulnerable on the grounds that it has acted arbitrarily." Id. at 6-7 (quoting David Weisbach \& Cass R. Sunstein, Climate Change and Discounting the Future: A Guide for the Perplexed, 27 YALE L. \& POL'Y REV. 433, 443-44 (2009)). Martin Weitzman also has defended hyperbolic discounting on the ground that uncertainty over the appropriate discount rate should favor lower rates in order to avoid the undue dominance by higher rates that would follow if discount rates are turned into discount factors over a time series and averaged together. Id. at 19 (citing Martin L. Weitzman, Gamma Discounting, 91 Am. Econ. Rev. 260 (2001); Martin L. Weitzman, Just Keep Discounting, But..., in Discounting AND InTERGENERATIONAL EqUity 23 (Paul R. Portney \& John P. Weyant eds., 1999); Weitzman, supra note 82). 
regulatory measures. ${ }^{95}$ Modeling a sustainable market economy in this way will generate a hypothetical interest rate that regulatory analysts might then use to discount future costs and benefits when evaluating policies. Significant intergenerational policy issues like climate change regulation will look dramatically different when evaluated in this way. If we first endow future generations with the right to a relatively safe and stable concentration of greenhouse gases in the atmosphere-as physical scientists implicitly urge when they propose maximum climate change thresholds such as a $2^{\circ} \mathrm{C}$ temperature increase over pre-Industrial levels or a 350 parts per million carbon dioxide concentration limit-then the present generation would be required to "purchase" those rights from future generations using prices that reflect a normatively defensible background allocation of atmospheric rights. As it is, conventional cost-benefit analysis proceeds as if the present generation owns everything, implicitly answering with neither analysis nor defense a question that lies at the very core of the climate change policy problem. Importantly, this question cannot be avoided even if one adopts the mainstream welfare economic view that future generations can be "compensated" through undifferentiated accumulation of capital whenever specific natural resources are compromised-even ones as basic and seemingly nonsubstitutable as atmospheric stability. Even on this bullish view, the level of "compensation" that is due to future generations must be calculated in a way that first asks who owns the resources that have been destroyed. Any other procedure allows the present generation to play lord in a game of temporal feudalism.

\section{LOST IN TRANSLATION}

One way of understanding regulatory impact analysis is as an instrument for exercising centralized executive control over a vast federal administrative state, even occasionally against the wishes of the Congress that creates, funds, and instructs the relevant agencies. ${ }^{96}$ On this account, the continuity of federal

95. Cf. Joshua Farley, The Role of Prices in Conserving Critical Natural Capital, 22 CONSERVATION BIOLOGY 1399, 1406 (2008) (arguing that climate conservation should be market-determining, not market-determined).

96. In this respect, Livermore and Revesz may understate the impact of changes to regulatory oversight adopted during the George W. Bush Administration, which they describe as "relatively minor changes." Livermore \& Revesz, supra note 1 , at 7, 15. Those reforms, which were nominally rescinded by the Obama Administration, would have subjected all federal agency guidance documents to OIRA oversight and would have appointed a White House policy officer within each agency to ensure that cost-benefit analysis was applied earlier in the rulemaking process than currently practiced, irrespective 
cost-benefit practice over the last several administrations would say less about a genuine bipartisan embrace of the methodology than it does about the consistency of presidential interest in consolidating administrative authority and expanding White House policy influence. Partly in response to this view, many cost-benefit reformers-Livermore and Revesz chief among them-have called for greater disclosure and transparency in the regulatory oversight process. ${ }^{97}$ The OMB under President Obama claims to agree, ${ }^{98}$ and indeed Livermore and Revesz in their address applaud OMB and OIRA for the widespread public participation that occurred during the review process for a possible new executive order on regulatory review. ${ }^{99}$ The authors fail to note, however, that the Obama Administration initially indicated no such interest in public input for the executive order review and only opened the process to comment after pressure from nongovernmental organizations like the Center for Progressive Reform. ${ }^{100}$ Similarly, the role of OIRA in diluting the EPA's rulemaking on coal ash only came to light after the EPA inadvertently (or perhaps with apparent inadvertence) released OIRA's markup on the agency's website. ${ }^{101}$ In point of fact, OIRA operates with remarkably little accountability: no congressional committee or subcommittee exercises direct oversight, and no citizen suit provision ensures an opportunity for judicial review of OIRA decisions. ${ }^{102}$ The Obama Administration has done little

of whether the statutes being implemented called for-or even permitted-cost-benefit analysis. Curtis W. Copeland, Cong. Research SerV., RL 33862, Changes to the OMB REGULATORY REVIEW PROCESS BY EXECUTIVE ORDER 13422, at 5-12 (2007).

97. REVESZ \& LIVERMORE, supra note 2, at 171-72.

98. See 2009 OMB REPORT, supra note 21 , at 43 ("[C]areful regulatory analysis, if transparent in its assumptions and subject to public scrutiny, should be seen as part and parcel of open government.").

99. See Livermore \& Revesz, supra note 1, at 13-14.

100. See Letter from Rena Steinzor, President, Ctr. for Progressive Reform, to Peter Orszag, Dir., Office of Mgmt. \& Budget (Feb. 20, 2009), available at http://www.progressivereform.org/articles/PreliminaryCommentsonNewEO-Orszag.pdf. Compare Obama Memorandum, supra note 10 (directing OIRA to encourage public participation), with Federal Regulatory Review, 74 Fed. Reg. 8819, 8819 (Feb. 26, 2009) ("Executive Orders are not subject to notice and comment procedures, and as a general rule, public comment is not formally sought before they are issued. In this case, however, there has been an unusually high level of public interest, and because of the evident importance and fundamental nature of the relevant issues, the Director of OMB invites public comments on the principles and procedures governing regulatory review.").

101. See Document Details-Doc. ID: EPA-HQ-RCRA-2009-0640-0350, REGULATIONS.GOV, http://www.regulations.gov/\#!documentDetail;D=EPA-HQ-RCRA-20090640-0350 (last visited Feb. 12, 2011) ("This document was posted on this public site in error by EPA."); see also Interagency Working Comments, supra note 49 (open document by clicking on the PDF icon).

102. See Curtis W. Copeland, The Role of the Office of Information and Regulatory Affairs in Federal Rulemaking, 33 FORDHAM URB. L.J. 1257, 1263, 1309-10 (2006) 
to alter this basic problematic dynamic. Nor has the administration seemed particularly enthusiastic about stemming the trend toward greater and greater "presidential administration." ${ }^{103}$ For instance, at least in the context of EPA's effort to provide guidance on dioxin, OIRA has continued to follow a Bush Administration executive order subjecting agency guidance documents to OIRA review, even though the Obama Administration purported to rescind that order. ${ }^{104}$

The democracy-enhancing potential of regulatory impact analysis is easy to state but difficult to observe. Invariably, cost-benefit analyses of proposed regulations are dense, jargony, and opaque; inevitably, they contain moments deep within their technical details in which the analyst masks a critical value choice through a methodological maneuver. ${ }^{105}$ Perhaps if the foundational value questions at the heart of cost-benefit analysis were opened up for democratic negotiation-such as the debate over willingness-to-pay as the default value metric or the best way to consider the rights of future generations-then the public could start playing a more active role. But those questions are typically treated by cost-benefit proponents as matters of elite expertise or disciplinary orthodoxy, rather than debatable moral and political issues. As a result, the prevailing assumptions and principles of cost-benefit analysis are rarely subjected to transparent and sustained critique, even though they often work to stack the deck against aggressive regulatory action on behalf of environmental, health, and safety protection. Even the interagency task force on the social cost of carbon, which in many respects was a model of open and self-critical disciplinary examination, nevertheless balked at key moments in its analysis just as foundational questions were coming into view, the answers to which might well have justified far greater levels of greenhouse gas emissions mitigation. ${ }^{106}$

(discussing concerns that OIRA's regulatory review process lacks transparency and congressional oversight).

103. See Elena Kagan, Presidential Administration, 114 HARV. L. REV. 2245, 2281-2319 (2001) (describing the evolution and growth of presidential administration during the Clinton Administration).

104. CPR's Eye on OIRA, CTR. FOR PROGRESSIVE REFORM, http://www.progressivereform.org/eyeonoira.cfm (last visited Mar. 5, 2011).

105. For a detailed case study involving OIRA's successful effort to force EPA to dilute Section 316(b) of the Clean Water Act, see Douglas A. Kysar, Fish Tales, in Alternative Approaches to Regulatory Impact Analysis: A Dialogue Between Advocates and Skeptics of Cost-Benefit ANalysis 190 (Winston Harrington et al. eds., 2009).

106. For instance, the task force admirably refused to limit its analysis of climate change impacts to the United States alone, instead calculating both a domestic and global 
Livermore and Revesz argue that this "antiregulatory bias" associated with cost-benefit analysis and OIRA review is a "mirage."107 But the examples they highlight of how political actors and citizens groups can "[p]romot[e] an [a]ggressive [r]egulatory [a]genda with [c]ost-[b]enefit [a]nalysis" fall short of proving this case. ${ }^{108}$ The authors begin by noting that the Obama Administration has used cost-benefit analysis to publicly defend some of its regulatory initiatives, including implementation of the Clean Air Act with respect to greenhouse gas emissions. ${ }^{109}$ This observation tells us little about what factors drove the President in some contexts to use cost-benefit analysis to support agency proposals (e.g., automobile fuel efficiency standards) but in others to use the same methodology to attack them (e.g., coal ash disposal). Moreover, the agency actions cited by Livermore and Revesz were in almost all cases driven by statutory provisions that require health-based, technology-based, or other non-cost-benefit-based standards for implementation. Nor do the examples offered by Livermore and Revesz of how protection-oriented groups are more effectively using cost-benefit analysis undermine the long-standing association of cost-benefit analysis with a deregulatory agenda. The first two examples-of reproductive rights groups arguing against the Church Amendment and of the National Wildlife Federation opposing government subsidies for flood insurance-show progressive organizations successfully using cost-benefit analysis to criticize existing or proposed regulations, not to propose and defend new ones. ${ }^{110}$ The third example-of various groups using cost-benefit measures to redirect criminal justice spending-supports the

social cost of carbon (albeit one in which extraterritorial impacts were valued in a way that may have severely underestimated their actual welfare significance). See TASK FORCE REPORT, supra note 62, at 10 ("As a matter of law, consideration of both global and domestic values is generally permissible ....”. The task force's reasoning for considering the matter in question, however, was odd. The task force observed that "federal statutes are presumed not to have extraterritorial effect, in part to ensure that the laws of the United States respect the interests of foreign sovereigns." Id. at 10 n.6. A presumption against extraterritorial application of U.S. laws does in fact respect the sovereign authority of foreign nations. But a presumption that U.S. laws have no extraterritorial impact would do exactly the opposite: it would treat all extraterritorial consequences of U.S. laws and activities as unpriced externalities, making the world into the United States' waste bin, which is hardly a measure of "respect." Whether to apply U.S. law to extraterritorial conduct is an entirely separate question from whether to consider extraterritorial impacts when fashioning the content of U.S. law and policy. That the task force felt required to defend its consideration of the latter reveals how far a default position of insularity and isolationism has overtaken U.S. politics.

107. Livermore \& Revesz, supra note 1 , at 27.

108. Id. at 27 .

109. Id. at $27-29$.

110. Id. at $29-32$. 
idea that regulatory impact analysis can help "rationalize," i.e., shrink, an existing area of government expenditure, not that it can justify greater levels or new areas of expenditure. ${ }^{111}$ The fourth example-of mainstream environmental organizations commenting on the interagency social cost of carbon exercise-shows only increasing engagement by advocacy groups with the cost-benefit methodology, not that the methodology has led to demonstrated improvements in environmental, health, and safety regulation. ${ }^{112}$ For reasons discussed in Part II, the social cost of carbon is likely to confuse and weaken the climate change policy agenda, rather than to strengthen it.

Indeed, early experience with the social cost of carbon suggests that it has not altered the political dynamics of regulatory cost-benefit analysis. Most notably, the EPA and NHTSA recently proposed the first ever U.S. standards for fuel efficiency and greenhouse gas emissions for heavy-duty trucks and buses. ${ }^{113}$ Overall, the agencies estimate that the program will provide $\$ 41$ billion in net benefits over the lifetime of model year 2014 to 2018 vehicles, an astonishing amount that was driven in part by climate change benefits (valued using a social cost of carbon set at $\$ 22$ per ton and discounted at 3\%), but primarily by cost savings to truckers from lower fuel expenditures. ${ }^{114}$ Given this remarkable level of low-hanging fruit from fuel savings alone-and given the fact that the agencies did not quantify any of the long list of non-greenhouse gas environmental and human health benefits associated with reducing heavy truck emissions-one might strongly suspect that the proposed standard is inefficiently low. Indeed, the National Research Council report mandated by Congress to guide agency decisionmaking in this area recommended stronger standards than those proposed by EPA and NHTSA, ${ }^{115}$ and administration officials conceded that the proposed standards are

\footnotetext{
111. Id. at 32 .

112. Id. at 33 .

113. Comm. to Assess Fuel ECON. TeChs. For MEdium- AND HeAvy-Duty Vehicles, NAT'L Research Council, TeChNOlogies AND ApPROAChes to REDUCing the Fuel Consumption of MEDIUM- AND HeAvy-Duty VeHICles 1 (2010), available at http://www.nap.edu/catalog/12845.html [hereinafter CoMM. TO ASSESS FUEL ECONOMY]; see also Energy Independence and Security Act of 2007, Pub. L. No. 110-140, § 108, 121 Stat. 1492, 1505.

114. OfFICE of Transp. \& AIR QUALITY, EPA \& NHTSA, EPA AND NHTSA PRopose First-Ever Program to Reduce Greenhouse Gas Emissions and ImProve Fuel EFFiciency of Medium-ANd HeAvy-Duty Vehicles: REgulatory ANNOUNCEMENT 2, 3 \& n.4 (2010).

115. COMm. To Assess Fuel ECONOMY, supra note 113, at 5-8, 39.
} 
"significantly less ambitious" than recommended in order "to keep costs manageable." Moreover, this determination appears to have been made "after extensive consultation with manufacturers and trucking companies and a detailed review by the White House Office of Management and Budget."117 Considering the enormous monetary values generally associated with reducing ambient ozone, particulate matter, and air toxics, and the fact that "[r]esource and time constraints precluded the [EPA] from completing [quantification of these benefits] in time for the proposal," agencies in a different direction than it apparently did.

Livermore and Revesz are undoubtedly correct that cost-benefit analysis is likely to be a fixture of the regulatory state for years to come and that at least some segments of the environmental, health, and safety advocacy community ought to get good at using it so that antiregulatory forces do not exert monopoly power over its principles and assumptions. But, at the same time, alternative languages for identifying and urging progressive goals should not be abandoned entirely as their translation into the cost-benefit vernacular will be rough and potentially counterproductive. Consider an example from Adam Finkel, one of cost-benefit analysis's most thoughtful proponents, who recently suggested that progressive supporters of same-sex marriage would do better to rest their case on cost-benefit analysis than on equality-based moral reasoning that might appear to be easily stalemated by arguments from religion, natural law, and other such comprehensive moral schemes. On the cost-benefit account, readily monetizable benefits to the wedding industry alone would seem to carry the day in favor of legalizing same-sex marriage, easily trumping whatever amount of intangible disutility could be adequately demonstrated, quantified, and monetized by those individuals and groups who stand opposed to same-sex marriage ${ }^{119}$ Finkel's example follows a longstanding but underappreciated strand of the utilitarian tradition: one of utilitarianism's most elegant defenses has been that the theory is best used not as an all-encompassing program for individual or collective action but instead as a heuristic device

116. Broder, supra note 114.

117. Id.

118. EPA, Draft Regulatory ImpaCt ANAlysis: Proposed Rulemaking to Establish GREEN-HOUSE GAS EMissions STANDARDS AND FuEL EFFICIENCY STANDARDS FOR MEDIUM- AND HEAVY-DUty ENGINES AND VeHICles 8-38 (2010), available at http://www.epa.gov/otaq/climate/regulations/420d10901.pdf.

119. Adam Finkel, Book Review, 53 J. OCCUPATIONAL \& ENVTL. MED. 101, 102 (2011) (reviewing KYSAR, supra note 96). 
to uncover neglect, marginalization, and oppression within a given social order. ${ }^{120}$ Bentham and Mill, after all, are well remembered not only for their theoretical contributions but also for their early and prescient championing of equal rights for women, emancipation of slaves, and legal protection of nonhuman animals. ${ }^{121}$ By narrowing the pertinent question to a seemingly narrow and objective one-for example, as Bentham asked of animals, "Can they suffer?"-the utilitarian approach rules out a range of arguments that might otherwise seem to justify a rigid and unjust status quo. ${ }^{122}$

Nevertheless, this progressive tilt to utilitarianism is actually only half of a seesaw, for it is always possible that the empirics might come out differently than progressive proponents urge. Bentham and his latter-day followers like Peter Singer may be right that animals can suffer and that this fact alone justifies the moral considerability of animals, ${ }^{123}$ but a full utilitarian logic requires balancing whatever animal disutility has been demonstrated against the utility generated (for humans) by factory farming, medical experimentation, habitat destruction, and other activities through which animals suffer and perish. As Part II suggests, these calculative exercises do not depend ultimately on rigid empirical facts, but rather on contestable features of the epistemic practices by which facts are thought to be discovered and valued. Thus, to return to Finkel's example, the apparent desirability of same-sex marriage under cost-benefit analysis does not represent some fixed truth about the physics of

120. See Jedediah Purdy, The Meaning of Property: Freedom, Community, and THE LEGAL IMAGINATION 122 (2010) (describing the value of utilitarianism as "a potency to lay bare injustice").

121. See Lea Campos Boralevi, Bentham AND the Oppressed 5-36, 144 (1984) (analyzing Bentham's contribution to feminism and comparing his views regarding oppression of women and slaves); John STUART Mill, THE SUBJECTION OF WoMEN 28-29 (London, Longmans, Green, Reader \& Dyer 1896) (arguing against presumptions that "place women in social and political subjection to men"); John Stuart Mill, Utilitarianism, in JUSTICE: A READER 14, 37 (2007) ("Even in slave countries it is theoretically admitted that the rights of the slave, such as they are, ought to be as sacred as those of the master ... ."); Gary L. Francione, Animals-Property or Persons?, in ANIMAL Rights 108, 113 (Cass R. Sunstein \& Martha C. Nussbaum eds., 2004) (attributing Bentham with the origination of humane animal treatment principles); Gary L. Francione \& Anna E. Charlton, Abolitionist Approach to Animal Rights, in 1 ENCYClOPEDIA OF ANIMAL RIGHTS AND ANIMAL WELFARE (Marc Bekoff ed., 2d ed. 2010) ("Jeremy Bentham and John Stuart Mill argued that animals deserved to be included in the moral community and given at least some legal protection ....").

122. Jeremy Bentham, AN Introduction to THE PRINCIPLES OF MORALS AND LEGiSlation 310 n.1 (Hafner Publ'g Co. 1948) (1781).

123. See Peter Singer, All Animals Are Equal, in ANIMAL Rights AND Human OBligations 148, 152-54 (Tom Regan \& Peter Singer eds., 1976) (arguing that utilitarian principles support advocating for equal rights for animals). 
"welfare," but rather only the contingent outcome of a socio-political battle to generate authoritative constructs of "welfare." Victory on such a plane is necessarily shallow: even if the empirics never change-that is, even if opponents of same-sex marriage never succeed in constructing an alternative welfare exercise under which their disutility swamps the demonstrated benefits of equal marriage opportunity-those who support same-sex marriage will have not achieved the victory they seek. The true goal of same-sex marriage proponents is equal recognition and respect for same-sex marriage partners, something that cannot adequately be captured or justified by a happenstance and always revisable calculation of welfare.

To switch the example's political valence but maintain its analysis intact, it is not all that "strange," as Livermore and Revesz suggest, that Sunstein's nomination as the head of ORIA got held up on the issue of animal rights and his support for gun control measures. ${ }^{124}$ As Dan Kahan and Donald Braman have persuasively shown, political debates about gun control have very little to do with the empirical consequences of gun control measures and much to do with whether those measures affirm or discredit individuals' cultural worldviews. ${ }^{125}$ Because he is a thoroughgoing welfarist, Sunstein came rather smoothly to the conclusion that animals might "count" for public policy purposes and that their suffering might justify some form of legal restriction on hunting and other harmful activities. But gun rights advocates think through different concepts than these and no a priori reason exists for believing that their thinking is inferior to welfarists. Indeed, the objection of gun rights advocates to Sunstein's nomination was not altogether different from that of environmentalists: both groups seek the instantiation into law of values and principles that they regard as inviolable. ${ }^{126}$ Sunstein, instead, has come to stand for the position that everything is violable, for violability is the intellectual core of the welfarist-utilitarian reasoning that he has promoted. Indeed, much about American politics is revealed

124. Livermore \& Revesz, supra note 1, at 16-17; Peter Nicholas, More than Healthcare Rides on Obama's Speech; His Address Is Meant to Revive Reform Efforts, L.A. TIMES, Sept. 9, 2009, at A1.

125. See Dan M. Kahan \& Donald Braman, More Statistics, Less Persuasion: A Cultural Theory of Gun-Risk Perceptions, 151 U. PA. L. REv. 1291, 1295-1301 (2003) (presenting evidence that views on gun control are shaped by cultural orientation rather than empirical data).

126. See id. at 1299-1301 (arguing that gun control activists are more concerned with projecting their values and principles into law than making policy based on empirical data). 
by the fact that Sunstein's welfarism alienated both those who seek unchecked freedom in human weaponry and those who seek responsible liberation in nonhuman care. If politics makes strange bedfellows, it also makes strange common enemies.

A similar analysis applies to Livermore and Revesz's discussion of the Church Amendment and the scholars' effort to assist reproductive rights advocates in demonstrating the welfare consequences of restricting the availability of abortion procedures. ${ }^{127}$ If welfarism prevails as the determinant of public policy, such restrictions on abortion procedures might well be overturned. But this result will not have answered the objections of abortion opponents on their own terms. Specifically, it will not have resolved whether a life conceived is a life with moral and political considerability that definitively outweighs the liberty interests of its mother (and, to a lesser but not unreal extent, its father). Any thoroughgoing cost-benefit analysis of the Church Amendment would have to make some determination about whether to count the utility lost by those individuals who never come to be due to wider availability of abortion procedures. Through this determination, the ultimate moral question raised by abortion would be implicitly answered, but in a way that neither side of the abortion debate is likely to find adequately expressive of their views. The basic mistake here lies in thinking that there can be a universally agreeable secular-liberal welfarism, toward which we might "nudge" our political agents and underneath which their principals might submit. Any such welfarism would remain inherently and perpetually contestable. Most basically, as just noted, such a welfarism must establish who "counts" for purposes of welfare calculation: Only presently living American citizens (or also lawful residents-or even undocumented residents-living in America)? What about individuals living in other nations? What about nonhuman animals, wherever they live? What about the conceived unborn, i.e., those lives in being/becoming that have dominated American politics for decades without any resolution as to who/what they "are"? What about the unconceived unborn, i.e., those future generations who figure prominently in the politics of the same environmentalists who generally oppose abortion restrictions, but who lack an adequate account of why they appear to care more for the unconceived unborn than the conceived?

Even if these vexing questions were somehow resolved, one still must establish methods for valuing welfare consequences to

127. Livermore \& Revesz, supra note 1, at 29-31. 
the acknowledged beneficiaries of cost-benefit analysis, as well as weights for adjusting those consequences in light of the diverse socioeconomic, geographic, and temporal positions that the acknowledged beneficiaries will occupy. In this respect, if we continue to force cost-benefit analysis on agencies, then we should also force them to use multiple alternative measures of welfare. Present practice dictates that only one value metric-usually willingness-to-pay-is used to determine the monetary worth of policy consequences. This approach has a dramatically conservative effect. It essentially privileges the status quo distribution of rights and resources, so that any policy other than a minor nudge from existing patterns appears to have a large efficiency "cost" that must be justified by even greater benefits. Our problems demand a greater degree of ethical imagination than this. Just as OMB bravely acknowledged with respect to GDP on the macroeconomic level, ${ }^{128}$ it should acknowledge on the microeconomic level that a single conception of value such as willingness-to-pay will never be adequate for our needs. Irrespective of which metric we choose to ground welfare analysis, the danger arises that it will come to crowd out other ways of conceptualizing well-being and promoting its attainment; significant questions will become effectively embargoed because the optimizing logic of cost-benefit analysis will attach an efficiency "cost" to any deviation from its norms of evaluation. By requiring agencies instead to present cost-benefit data using alternative value metrics, we might prompt serious discussion regarding the merits of competing welfare criteria. Cost and benefit data might then become denaturalized, especially as they pertain to the existing pattern of right and resource distribution.

At one point in its report, the task force on the social cost of carbon valiantly acknowledged that diminishing marginal utility of income is a safe assumption, such that the calculation of welfare should not be based on measures such as GDP per capita that are parasitic on the existing distribution of wealth. ${ }^{129}$ But the task force oddly declined to adopt that assumption out of deference to the ideological presuppositions of the current state of the economics discipline, which prefers to value using metrics that privilege the status quo distribution of wealth and power in society and across the globe, while relegating redistribution to

128. OMB's 2009 report to Congress noted that the prevailing macroeconomic measure of national welfare (GDP)—often taken as the very raison d'etre of the nation-state-is hardly our only or even our most important measure of collective progress. 2009 OMB REPORT, supra note 21, at 29.

129. TASK FORCE REPORT, supra note 62, at 11. 
the category of equity as opposed to efficiency. ${ }^{130}$ A more honest debate over welfare economics and cost-benefit analysis would recognize that the choice of value metric is an ultimate moral and political choice. It is a choice that will itself determine what counts as "efficient," "maximizing," "optimal," and all other presumptively "good" things versus what will count as "redistribution," "altruism," "charity," and all other presumptively "optional" things. To lose this choice is to start the game with an enormous handicap, and that explains to a great extent why proponents of environmental, health, and safety regulation have been reluctant to heed Livermore and Revesz's advice to join the effort. The game as currently played is rigged against them and submitting to its ground rules might seem to endorse those rules as somehow justified. If value metrics other than GDP and willingness-to-pay predominated within the welfare economics profession, then the interests that would benefit from such an alternative metric would come a-calling, no doubt. Until such a transformation occurs, however, environmental, health, and safety proponents may be forgiven for questioning whether it really is better to play cost-benefit analysis rather than to attack its foundations.

\section{CONCLUSION}

The very title, Retaking Rationality, suggests a battlefield to be regained through power, rather than a scientific or academic effort to forge consensus through reason and empiricism. One suspects, then, that Livermore and Revesz are aware that regulatory cost-benefit analysis may only represent lobbying in a different, more specialized vernacular: politics by other meanings. Nevertheless, assuming Livermore and Revesz are correct that cost-benefit analysis is here to stay-and this Author has no reason to doubt their prediction-then proponents of environmental, health, and safety regulation would do well to start talking the talk as best they can. What they should not do, however, is convince themselves that the translation of their goals and values into cost-benefit terms will be lossless. Cost-benefit analysis is a language spoken by few and dominated by even fewer. Its diction is poor though it

130. See id. at 11 ("Notwithstanding the theoretical claims on behalf of equity weighting, the interagency group concluded that this approach would not be appropriate for estimating a [social cost of carbon] value used in domestic regulatory analysis."). More specifically, the task force did not change the assumption used in the integrated assessment models that mortality should be valued using country and region-specific per capita income measures. $I d$. at $6-8$. 
purports to speak everything meaningful. At least some, then, should follow Solzhenitsyn's advice: "Let [the lie] come into the world and even reign over it, but not through me."131 